\title{
Biomass and concentration of nutrients and silicon in sugarcane grown on soil fertilized with diatomite
}

Katerin Manuelita Encina Oliva ${ }^{1} \odot$, Clístenes Williams Araújo do Nascimento ${ }^{1}$, Fernando Bruno Vieira da Silva $^{1} \oplus$,

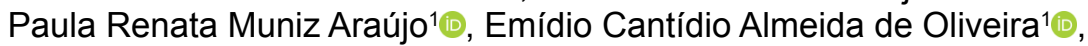

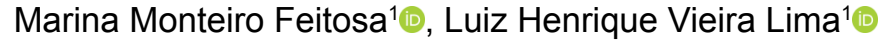

\footnotetext{
1 Universidade Federal Rural de Pernambuco, Recife, PE, Brasil. E-mail: kattyencinao@gmail.com; clistenes.nascimento@ufrpe.br; ferbruno01@yahoo.com.br; paula_agronomia11@hotmail.com; emidio.oliveira@ufrpe.br; marinamonteirof@gmail.com; luizhenrique.vieira@hotmail.com
}

ABSTRACT: Silicon (Si) plays an important role in sugarcane, but there is a gap of information regarding the potential of diatomite as a Si fertilizer to this crop. Here, we assessed the effects of five rates (equivalents to 75; 150;225; 300 and $375 \mathrm{~kg} \mathrm{ha}^{-1} \mathrm{Si}$ ) of a diatomite-based fertilizer on the biomass yield and concentration of nutrients and $\mathrm{Si}$ in sugarcane plants grown on a sandy soil. The efficiency of the extractants acetic acid and calcium chloride in predicting Si uptake was also assessed. Results showed that diatomite was efficient in supplying available $\mathrm{Si}$ in the soil and increased $\mathrm{Si}$ concentration in the plant. The addition of diatomite significantly increased the available contents of $\mathrm{P}, \mathrm{K}, \mathrm{Mn}, \mathrm{Cu}$, and the cationic exchangeable capacity of the soil. The concentrations of $\mathrm{N}, \mathrm{P}, \mathrm{Mn}, \mathrm{Cu}$, and $\mathrm{Zn}$ in shoots were elevated, suggesting that the fertilizer can play a role in the efficient use of nutrients by sugarcane. The extractant $0.01 \mathrm{~mol} \mathrm{~L}^{-1} \mathrm{CaCl}_{2}$ was better correlated with Si concentration in plants than $0.5 \mathrm{~mol} \mathrm{~L}^{-1}$ acetic acid. Therefore, $\mathrm{CaCl}_{2}$ is the recommended extractant to estimate $\mathrm{Si}$ availability because of its higher efficiency and lower cost.

Key words: amorphous silicate; diatomite; mineral nutrition; sandy soils; soil fertility

\section{Biomassa e concentração de nutrientes e silício em cana-de-açúcar cultivada em solo adubado com diatomita}

RESUMO: O silício (Si) desempenha um papel importante na cana-de-açúcar, mas há pouca informação sobre o potencial da diatomita como fertilizante de Si para esta cultura. No presente estudo, avaliamos os efeitos de cinco doses (75; 150;225; 300 e $375 \mathrm{~kg} \mathrm{ha}^{-1} \mathrm{Si}$ ) de um fertilizante à base de diatomita na produção de biomassa e na concentração de nutrientes e Si em plantas de cana-de-açúcar cultivadas em um solo arenoso. A eficiência dos extratores ácido acético e cloreto de cálcio na previsão da absorção de Si também foi avaliada. Os resultados mostraram que o fertilizante foi eficiente em fornecer Si disponível no solo e aumentar a concentração de Si na planta. A adição de diatomita aumentou significativamente os teores disponíveis de $\mathrm{P}, \mathrm{K}$, $\mathrm{Mn}, \mathrm{Cu}$ e a capacidade de troca catiônica do solo. As concentrações de N, P, Mn, Cu e Zn na parte aérea foram aumentadas, sugerindo que o fertilizante pode desempenhar um papel no uso eficiente dos nutrientes pela cana-de-açúcar. $\mathrm{O}$ extrator $\mathrm{CaCl}_{2}$ $0,01 \mathrm{~mol} \mathrm{~L}^{-1}$ foi mais eficiente em estimar a concentração de Si nas plantas do que ácido acético $0,5 \mathrm{~mol} \mathrm{~L}^{-1}$. Portanto, o CaCl deve ser o extrator recomendado para estimar a disponibilidade de Si devido a sua maior eficiência e menor custo.

Palavras-chave: silicato amorfo; diatomita; nutrição mineral; solos arenoso; fertilidade do solo 


\section{Introduction}

Silicon (Si) is an abundant metalloid in the earth's crust and beneficial to plants, alleviating stresses caused by drought (Amin et al., 2018), salinity (Wang et al., 2015), metals (Nascimento \& Cunha, 2015), pests and diseases (Liang et al., 2015). Si-supplied plants, especially graminaceous species such as maize, rice, and sugarcane, may show higher yields and better nutritional status and quality when fertilized with Si (Keeping, 2017).

The total Si concentration in most soils is over $50 \%$, but it is mainly found as $\mathrm{SiO}_{2}$ in a wide variety of Si-bearing minerals in crystalline, poorly crystalline, and amorphous phases (Tubana et al., 2016), therefore not available for plant uptake. Silicon bioavailability is very low because of the slow release of Si from mineral weathering and low contribution of organic matter decomposition. Besides, the Si exportation by crops and soil desilication process continuously depletes the Si available concentration in the soil (Liang et al., 2015). Yield responses to Si take place especially in soils containing a low concentration of available silicon. Studies in Si-deficient soils $\left(<10 \mathrm{mg} \mathrm{kg}^{-1} \mathrm{Si}\right)$ have shown that silicate fertilization promotes a significant increase in the yield of sugarcane and improvement in parameters such as fiber and total reducing sugar (Camargo et al., 2013).

Silicon fertilizers can increase nutrient uptake by optimizing soil fertility, plant water use, and soil physical and chemical characteristics (Eneji et al., 2008; Greger et al., 2018; Nascimento et al., 2020). For instance, Si fertilizers can contribute to the retention of water and cations in the soil (Pati et al., 2016). Eneji et al. (2008) found that Si improved the biomass yield and $\mathrm{K}$ uptake in four graminaceous plants under drought stress. Higher $\mathrm{N}$ accumulation in plants fertilized with Si has been shown to cowpea (Mali \& Aery, 2008), rice (Pati et al., 2016), melon (Nascimento et al., 2020), and wheat (White et al., 2017). Increased efficiency of the use of $P$ by Si was also obtained for agricultural crops (Abdalla, 2010).

Brazil is the largest world producer of sugarcane, but the national mean sugarcane yield $\left(75 \mathrm{t} \mathrm{ha}^{-1}\right)$ is relatively low; the average yield in northeast Brazil is even lower, i.e., $56 \mathrm{t}$ $\mathrm{ha}^{-1}$ (Conab, 2020). Sugarcane in this part of the country is grown mainly on sandy soils. These soils are characterized by low cation exchange capacity (CEC), water retention, natural fertility, and organic matter, and deficient soil soluble $\mathrm{Si}$ contents (Crusciol et al., 2018). Thus, sugarcane cultivated on these depleted-Si soils can benefit from Si fertilization.

The plant-available Si concentrations in soil vary widely. A range of extractants, including unbuffered salts, acids, and acetic acids have been used to estimate the $\mathrm{Si}$ availability to crops. There is no universally adopted method (Haynes, 2014) so that extractants must be tested for several soil conditions. Diluted salt solutions such as $\mathrm{CaCl}_{2} 10 \mathrm{mmol} \mathrm{L}^{-1}$ have ionic strength similar to soil solution; therefore, they prevent soil dispersion and facilitates soil analyses (Miles et al., 2014). Acetic acid has also been intensively used as a Si extractant (Liang et al., 2015). This extractant partially dissolves amorphous Fe and $\mathrm{Al}$ oxides and amorphous aluminosilicates hence releasing the adsorbed Si (Haynes, 2014).

Several Si sources varying in total Si contents and solubility are used in Brazil. Most studies use calcium silicate $\left(\mathrm{CaSiO}_{3}\right)$ and slags (Camargo et al., 2017; Liang et al., 2015), and only a few studies tested diatomites as a Si source to crops (Nascimento et al., 2020). Diatomite is a sedimentary rock formed by the accumulation of diatom algal fossils and composed predominantly of amorphous silica $\left(\mathrm{SiO}_{2} \cdot \mathrm{nH}_{2} \mathrm{O}\right)$ (Sandhya \& Prakash, 2019). This study aimed to evaluate the effects of a diatomite-based fertilizer on the biomass yield and concentration of nutrients ( $\mathrm{N}, \mathrm{P}, \mathrm{K}, \mathrm{Fe}, \mathrm{Mn}, \mathrm{Cu}$, and $\mathrm{Zn}$ ) and $\mathrm{Si}$ in sugarcane plants grown on a sandy soil typical of the producing sugarcane region of NE Brazil. The soil Si availability by two extractants (acetic acid and calcium chloride) and the changes in soil chemical characteristics driven by diatomite were also assessed.

\section{Materials and Methods}

\section{Pot experiment}

The soil used in the experiment was collected at a depth of 0.0 - 0.2 m in Santa Rita - PB ( $6^{\circ} 56^{\prime} 43.4^{\prime \prime} S$ and $35^{\circ} 07^{\prime} 57.7^{\prime \prime}$ W) and is representative of many areas of sugarcane cultivation in NE Brazil. The soil was dried, sieved ( $2 \mathrm{~mm}$ mesh), and three subsamples were chemically and physically analyzed using standard methods (Embrapa, 2011). The pH was determined in the water at a 1:2.5 soil/water ratio. The determination of soil organic carbon used the Walkley-Black oxidation method. The $\mathrm{Ca}^{2+}$ and $\mathrm{Mg}^{2+}$ exchangeable contents were obtained with $1 \mathrm{~mol} \mathrm{~L}^{-1} \mathrm{KCl}$ solution and determined by titration. The available contents of $\mathrm{K}+, \mathrm{Na}+$ and $\mathrm{P}$ were extracted by Mehlich-1 and analyzed by flame photometry $(\mathrm{K}+, \mathrm{Na}+)$ and colorimetry $(\mathrm{P})$. The exchangeable $\mathrm{Al}^{3+}$ was measured by titration in the extract of the $1 \mathrm{~mol} \mathrm{~L}^{-1} \mathrm{KCl}$ solution. The potential acidity $(\mathrm{H}+\mathrm{Al})$ was determined by extraction with $0.5 \mathrm{~mol} \mathrm{~L}^{-1}$ calcium acetate at pH 7.0 and titration with $0.025 \mathrm{~mol} \mathrm{~L}^{-1} \mathrm{NaOH}$. The sum of bases - $\mathrm{SB}\left(\mathrm{Ca}^{2+}, \mathrm{Mg}^{2+}, \mathrm{K}^{+}, \mathrm{Na}^{+}\right)$was summed up to $\mathrm{H}^{+}+\mathrm{Al}^{3+}$ to obtain the cation exchange capacity (CEC). Soil particle-size distribution was determined using the Bouyoucos hydrometer method.

Soluble Si contents in the soil were evaluated by two extraction solutions: $\mathrm{CaCl}_{2}\left(0.01 \mathrm{~mol} \mathrm{~L}^{-1}\right)$ and acetic acid $(0.5$ $\mathrm{mol} \mathrm{L}^{-1}$ ) (Korndörfer et al., 1999). For Si analyses, 10 grams of soil were agitated for 1 hour with $100 \mathrm{~mL}$ of either acetic acid or $\mathrm{CaCl}_{2}$. Then, the supernatant was decanted and filtrated. Silicon concentration in the soil extracts was measured in a spectrophotometer at a wavelength of $660 \mathrm{~nm}$ through the molybdosilicic complex formation.

The results of soil analyses are shown in Table 1. The soil had a slightly alkaline $\mathrm{pH}$, low contents of organic matter and a general low natural fertility. Soil texture was sand. The soil was classified as an Arenosol (IUSS Working Group WRB, 2015). It was highly depleted in $\mathrm{Si}$, with $\mathrm{Si}$ available concentrations < $3.0 \mathrm{mg} \mathrm{kg}^{-1}$. 
Table 1. Chemical and physical characteristics of the soil used in the experiment.

\begin{tabular}{lcc}
\hline $\mathrm{pH}$ & water $(1: 2,5)$ & 7.6 \\
$\mathrm{Ca}^{2+}$ & $\mathrm{mmol}_{\mathrm{c}} \mathrm{kg}^{-1}$ & 10.0 \\
$\mathrm{Mg}^{2+}$ & $\mathrm{mmol}_{\mathrm{c}} \mathrm{kg}^{-1}$ & 7.0 \\
$\mathrm{~K}^{+}$ & $\mathrm{mmol}_{\mathrm{c}} \mathrm{kg}^{-1}$ & 0.5 \\
$\mathrm{Na}^{+}$ & $\mathrm{mmol}_{\mathrm{c}} \mathrm{kg}^{-1}$ & 0.0 \\
$\mathrm{Al}^{3+}$ & $\mathrm{mmol}_{\mathrm{c}} \mathrm{kg}^{-1}$ & 0.0 \\
$\mathrm{H}^{+}+\mathrm{Al}^{3+}$ & $\mathrm{mmol}_{\mathrm{c}} \mathrm{kg}^{-1}$ & 7.0 \\
$\mathrm{SB}$ & $\mathrm{mmol}_{\mathrm{c} \mathrm{k}}$ & 17.0 \\
$\mathrm{CEC}$ & $\mathrm{mmol}_{\mathrm{c}} \mathrm{kg}^{-1}$ & 7.4 \\
$\mathrm{P}$ & $\mathrm{mg} \mathrm{kg}^{-1}$ & 12.2 \\
$\mathrm{SOC}$ & $\mathrm{g} \mathrm{kg}^{-1}$ & 2.7 \\
$\mathrm{SOM}$ & $\mathrm{g} \mathrm{kg}^{-1}$ & 4.7 \\
$\mathrm{Si}$ & $\mathrm{mg} \mathrm{kg}^{-1}$ & 2.7 \\
Si & $\mathrm{mg} \mathrm{kg}^{-1}$ & 1.1 \\
Sand & $\mathrm{g} \mathrm{kg}^{-1}$ & 965.0 \\
Silt & $\mathrm{g} \mathrm{kg}^{-1}$ & 11.0 \\
Clay & $\mathrm{g} \mathrm{kg}^{-1}$ & 24.0 \\
Soil density & $\mathrm{g} \mathrm{cm}^{-3}$ & 1.5 \\
\hline
\end{tabular}

SB sum of bases; CEC cation exchange capacity; SOC soil organic carbon; SOM soil organic matter; $\mathrm{Si}_{\mathrm{a}}$ silicon available in the soil extracted with acetic acid $0,5 \mathrm{~mol} \mathrm{~L}^{-1}$; $\mathrm{Si}_{c}$ silicon available in the soil extracted with $\mathrm{CaCl}_{2} 0,01 \mathrm{~mol} \mathrm{~L}^{-1}$.

Prior do to the experiment set up, the soil was fertilized with macro and micronutrients at the following rates and sources based on Alvarez (1974) and Nascimento et al. (2006): $50 \mathrm{mg} \mathrm{dm}^{-3} \mathrm{~N}$ (Urea), $150 \mathrm{mg} \mathrm{dm}^{-3} \mathrm{~K} \mathrm{(KCl),} 400$ $\mathrm{mg} \mathrm{dm}{ }^{-3} \mathrm{P}$ (MAP), $40 \mathrm{mg} \mathrm{S} \mathrm{dm}^{-3}\left(\mathrm{~K}_{2} \mathrm{SO}_{4}\right), 3.664 \mathrm{mg} \mathrm{Mn} \mathrm{dm}^{-3}$ $\left(\mathrm{MnCl}_{2} \cdot 4 \mathrm{H}_{2} \mathrm{O}\right), 4 \mathrm{mg} \mathrm{Zn} \mathrm{dm}{ }^{-3}\left(\mathrm{ZnSO}_{4} .7 \mathrm{H}_{2} \mathrm{O}\right), 1.329 \mathrm{mg} \mathrm{Cu}$ $\mathrm{dm}^{-3}\left(\mathrm{CuSO}_{4}\right), 1.556 \mathrm{mg} \mathrm{dm}^{-3} \mathrm{Fe}\left(\mathrm{FeSO}_{4} .7 \mathrm{H}_{2} \mathrm{O}\right)$ and $0.15 \mathrm{mg}$ $\mathrm{dm}^{-3} \mathrm{Mo}\left(\mathrm{Na}_{2} \mathrm{MoO}_{4} \cdot 2 \mathrm{H}_{2} \mathrm{O}\right)$. Two three-months-old sugarcane seedlings, variety RB 06-1675 (developed by RIDESA Rede Interuniversitária para o Desenvolvimento do Setor Sucroalcooleiro), were transplanted to each $15 \mathrm{~L}$ pot; the soil was maintained at $80 \%$ of the water holding capacity throughout the experiment by weighting the soil and adding the required amount of water previously defined by the pot capacity method (Casaroli \& Jong van Lier, 2008). The pot experiment was carried out between and February and May 2018.

The treatments comprised five Si rates equivalents to 75 , $150,225,300,375 \mathrm{~kg} \mathrm{ha}^{-1}$ plus a control (without Si addition) applied as a diatomite fertilizer to pots containing $10 \mathrm{dm}^{-3}$ of soil (dry base). These rates were based on previous studies and economic feasibility for fertilizer use. Diatomite belongs to the group of silica-bearing rocks. It is originated from sedimentary materials consisting mainly of the fossilized skeletal remains of diatom, a unicellular aquatic plant related to the algae, during the tertiary and quaternary periods (Akin et al., 2000)

The source used was a granulated fertilizer $(2-5 \mathrm{~mm})$ produced from diatomite (Agrisilica@), which contains the following guarantees provided by the manufacturer: $29,1.4$, and $1.1 \%$ of total $\mathrm{Si}, \mathrm{Ca}$ and $\mathrm{Mg}$, respectively, cation exchange capacity $>50.0 \mathrm{cmol}_{\mathrm{c}} \mathrm{dm}^{-3}$, and trace concentrations of heavy metals (0.021;0.004; 0.003; 0.002; 0.002; 0.0003 and < $0.0001 \%$ for $\mathrm{Mn}, \mathrm{Cr}, \mathrm{Zn}, \mathrm{Cu}, \mathrm{Pb}, \mathrm{As}$ and $\mathrm{Cd}$, respectively).

\section{Chemical analysis of plants and soil samples}

The plant shoot was collected at 70 days after transplanting, then washed with distilled water, and dried at $65^{\circ} \mathrm{C}$. The biomass was recorded, and plant tissue was ground in a Willey-type knife mill. The Si concentration of shoots was determined according to the methodology proposed by Elliot \& Snyder (1991). Nitrogen was extracted by digesting $0.2 \mathrm{~g}$ of the plant material in concentrated sulfuric acid at $350^{\circ} \mathrm{C}$, according to the Kjeldahl method. Potassium, $\mathrm{P}, \mathrm{Cu}, \mathrm{Fe}, \mathrm{Mn}$, and $\mathrm{Zn}$ were determined in the digestion extract of $0.5 \mathrm{~g}$ of the samples in nitroperchloric solution at 200 ㅇ. .

Soil samples were collected at the end of the experiment for chemical analysis to assess the effect of diatomite on soil characteristics. The following analyses were performed: $\mathrm{pH}$; exchangeable $\mathrm{Ca}$ and $\mathrm{Mg}$; available concentrations of $\mathrm{Cu}, \mathrm{Fe}$, $\mathrm{Mn}, \mathrm{Zn}, \mathrm{K}$, and $\mathrm{P}$ extracted by Mehlich-1; cation exchange capacity (CEC) by the sodium/ammonium acetate method. Phosphorus concentration was obtained by colorimetry, while $\mathrm{K}$ was measured by flame spectrometry. Calcium and $\mathrm{Mg}$ in soil were determined by titration. The micronutrients $\mathrm{Cu}, \mathrm{Fe}, \mathrm{Mn}$, and $\mathrm{Zn}$ were measured by atomic absorption spectrometry. Silicon was determined by UV spectrometer through the formation of silicon-molybdate complexes.

Analytical quality control used blanks and a certified reference material SRM 1570a (Spinach Leaves) by the National Institute of Standards and Technology (NIST). All analyzes were performed in duplicate and element recoveries in the reference material ranged from 93 to $107 \%$.

\section{Statistical analyses}

The experiment was carried out in a greenhouse using a randomized complete block design and four replicates. The data were analyzed by applying ANOVA ( $F$ test). Regression analyses ( $p \leq 0.05$ ) were used to investigate the relationship of $\mathrm{Si}$ rates applied to the soil with biomass yield and concentration and content of $\mathrm{Si}$ in plants. The Si effect on soil characteristics and nutrients in plants were tested by Tukey ( $p \leq 0.05$ ). Pearson's correlation was used to assess Si soil extractants' efficiency in estimating Si concentration in plants. All statistical analyses were accomplished with the software Statistica 10.1.

\section{Results and Discussion}

\section{Diatomite effects on the soil chemical characteristics}

There was no significant effect $(p>0.05)$ on the $\mathrm{pH}$ and available $\mathrm{Mg}$ and Fe concentrations in the soil (Table 2). On the other hand, diatomite promoted a significant increase in the CEC and availability of $\mathrm{K}$ and $\mathrm{Mn}$ contents. The increase in CEC may be due to the high porosity (35 - 65\%), high permeability, low density, small particle size, and high specific surface area of diatomite (Bakr, 2010). Therefore, it is capable of retaining water and cationic ions owing to its CEC $>50 \mathrm{cmol}_{\mathrm{c}} \mathrm{kg}^{-1}$ (Pati et al., 2016). Increasing CEC in sandy soils is of great importance for soil fertility management, as it minimizes the leaching losses of $\mathrm{K}^{+}, \mathrm{NH}^{4+}$ and $\mathrm{Ca}^{2+}$ and increases the availability of 
Table 2. Mean values ( \pm standard deviation) of chemical and physical characteristics of the Arenosol fertilized with diatomite and cultivated with sugarcane for 70 days.

\begin{tabular}{|c|c|c|c|c|c|c|c|}
\hline \multirow{2}{*}{$\begin{array}{c}\text { Si } \\
\left(\mathrm{kg} \mathrm{ha}^{-1}\right)\end{array}$} & CEC & $\mathrm{K}^{+}$exchangeable & $\mathrm{Ca}^{2+}$ exchangeable & $\mathbf{P}_{\text {available }}$ & $M n_{\text {available }}$ & $\mathrm{Cu}_{\text {available }}$ & $\mathrm{Zn}_{\text {available }}$ \\
\hline & \multicolumn{3}{|c|}{$\left(\mathrm{mmol}_{\mathrm{c}} \mathrm{dm}^{-3}\right)$} & \multicolumn{4}{|c|}{$\left(\mathrm{mg} \mathrm{dm}^{-3}\right)$} \\
\hline 0.0 & $7.9 \pm 1.6 b$ & $0.4 \pm 0.1 b$ & $19.0 \pm 1.0 a$ & $9.2 \pm 2.1 b$ & $4.8 \pm 0.4 b$ & $0.9 \pm 0.1 b$ & $11.9 \pm 2.9 a$ \\
\hline 75.0 & $12.3 \pm 1.2 \mathrm{ab}$ & $0.6 \pm 0.1 \mathrm{ab}$ & $18.0 \pm 2.0 \mathrm{ab}$ & $12.0 \pm 1.5 a b$ & $8.2 \pm 1.6 a b$ & $1.3 \pm 0.2 \mathrm{ab}$ & $9.2 \pm 1.2 \mathrm{ab}$ \\
\hline 150.0 & $15.6 \pm 1.0 a$ & $0.8 \pm 0.2 a$ & $17.0 \pm 2.0 \mathrm{ab}$ & $14.7 \pm 1.4 \mathrm{ab}$ & $11.4 \pm 3.0 a$ & $1.5 \pm 0.2 \mathrm{ab}$ & $7.2 \pm 0.5 b$ \\
\hline 225.0 & $18.1 \pm 2.1 \mathrm{a}$ & $0.7 \pm 0.1 \mathrm{ab}$ & $15.0 \pm 1.0 \mathrm{~b}$ & $16.2 \pm 0.3 a b$ & $11.8 \pm 2.5 a$ & $1.6 \pm 0.1 \mathrm{ab}$ & $6.7 \pm 0.4 b$ \\
\hline 300.0 & $16.2 \pm 0.5 a$ & $0.7 \pm 0.2 \mathrm{ab}$ & $15.0 \pm 1.0 b$ & $18.5 \pm 5.8 \mathrm{a}$ & $8.4 \pm 0.8 \mathrm{ab}$ & $1.9 \pm 0.3 a b$ & $6.3 \pm 0.4 b$ \\
\hline
\end{tabular}

Values followed by the same letter in the column do not differ statistically by the Tukey test $(p>0.05)$. CEC cation exchange capacity.

these nutrients to the plant, as observed for $\mathrm{K}^{+}$in the present study.

Available soil $\mathrm{Ca}$ and $\mathrm{Zn}$ concentrations decreased with increasing silicate rates applied to the soil (Table 2). The availability decrease of these nutrients was probably due to the sugarcane nutrient removal. Other soil reactions can also contribute to this finding. For example, precipitation of $\mathrm{Ca}$ and $\mathrm{Zn}$ with phosphate $\left[\mathrm{Ca}_{3}\left(\mathrm{PO}_{4}\right)_{2} ; \mathrm{Zn}(\mathrm{OH}) \mathrm{H}_{2} \mathrm{PO}_{4}\right]$ and forms of silicic acid $\left[\mathrm{H}_{3} \mathrm{SiO}_{4}-\mathrm{H}_{2} \mathrm{SiO}_{4}{ }^{2-}, \mathrm{HSiO}_{4}{ }^{3-}\right.$ and $\left.\mathrm{SiO}_{4}{ }^{4-}\right]$ in the soil solution (Liang et al., 2015). Probably, the precipitation reactions of $\mathrm{Ca}$ and $\mathrm{Zn}$ ions with phosphate and silicate groups in the soil were more evident because of the soil $\mathrm{pH}$ value near neutrality, which geochemically favors the reaction of $\mathrm{Ca}^{+2}$ and $\mathrm{Zn}^{+2}$ with anionic groups (Matichenkov \& Bocharnikova, 2001). However, the reduction of these nutrients in the soil did not damage the plant growth, and the plants did not show deficiency symptoms.

The availability of $\mathrm{P}$ and $\mathrm{Cu}$ increased with the addition of diatomite to the soil. The rate of $375 \mathrm{~kg} \mathrm{ha}^{-1} \mathrm{Si}$ significantly increased by 115 and $300 \%$ the $\mathrm{P}$ and $\mathrm{Cu}$ concentrations compared to the control, respectively. The increase in $\mathrm{P}$ availability may be due to the higher activity of $\mathrm{H}_{3} \mathrm{SiO}_{4}^{-}$in soil solution promoting the exchange of ligands with the chemo-absorbed $\mathrm{H}_{3} \mathrm{PO}_{4}^{-}$ion in soil Fe and $\mathrm{Al}$ oxyhydroxides; to solubilization of the stable phase of Ca-bound phosphate (Matichenkov \& Bocharnikova, 2001). The increase in $\mathrm{Cu}$ was probably because phosphate and silicate anions have been sorbed into the soil organic groups, thus blocking the adsorption sites of the organic matter to the $\mathrm{Cu}$ and increasing its content in the exchangeable fraction of the soil.

Correlation between $\mathrm{Si}$ concentration in plants and soil $\mathrm{Si}$ extractants

The soil Si available concentrations in soil depended on the extractant used. $0.5 \mathrm{~mol} \mathrm{~L}^{-1}$ Acetic acid extracted $139 \%$ more Si than $0.01 \mathrm{~mol} \mathrm{~L}^{-1} \mathrm{CaCl}_{2}$ (Figure 1). Previous studies have reported a higher Si extraction capacity of acetic acid compared to $\mathrm{CaCl}_{2}$ (Camargo et al., 2013). However, acetic acid can lead to misinterpretation of Si availability. The extraction of Si with the acetic acid solution occurs at very low $\mathrm{pH}$ values $(1.0-2.0)$, which can super estimate $\mathrm{Si}$ availability by dissolving unavailable Si forms in the soil (Crusciol et al., 2018). In the present study, $\mathrm{CaCl}_{2}$ had a higher correlation with $\mathrm{Si}$ concentration in plants $(0.97, p<0.01)$ than acetic acid $(0.91, p<0.05)$ (Figure 2). Therefore, $\mathrm{CaCl}_{2}$ is the most recommend extractant for the sandy soils tested here. It is a neutral salt used at low molarity, which operationally provides the readily available Si concentrations in the soil solution (Liang et al., 2015).

\section{Biomass yield and $\mathrm{Si}$ accumulation in shoots}

The biomass and $\mathrm{Si}$ concentration in shoots of sugarcane were highly correlated and increased linearly with the increasing rates of diatomite applied to the soil (Figure 2). At the highest Si rate applied to the soil, biomass yield, and $\mathrm{Si}$ concentration in shoots increased 34 and $31 \%$, respectively, compared to the control, which demonstrates the potential of the fertilizer to supply Si and hence boost biomass yield.

Previous study has confirmed that silicate fertilization using $\mathrm{CaSiO}_{3}$ increases sugarcane biomass (Camargo et al., 2017). The Si effects on plant development are related to several ultrastructural, biochemical, and physiological changes. Among them, we can point out (i) increased root growth through cell wall extensibility, which results in the higher acquisition of water and nutrients; and, (ii) higher water use efficiency due to higher stomatal conductance, leaf water content, root hydraulic conductance for the whole plant and reduced transpiratory rate (Wang et al., 2015).

\section{Effects of diatomite on the plant nutrition}

Silicon can play an important role in the uptake, transport, and distribution of plant nutrients (Liang et al., 2015). Studies have confirmed that silicate fertilization significantly increases macro and micronutrient concentrations in plants (Garbanzo et al., 2018). Soil fertilization with diatomite induced greater nutrient uptake and translocation to the sugarcane shoots, except for $\mathrm{K}$ and $\mathrm{Fe}$ (Table 3 ). The $\mathrm{N}$ and $\mathrm{P}$ contents in the sugarcane shoot treated with $225 \mathrm{~kg} \mathrm{ha}^{-1}$ Si were significantly higher than the control ( 34 and 52\%, respectively). Manganese, $\mathrm{Cu}$ and $\mathrm{Zn}$, on the other, had their concentrations increased in shoots only for the Si rates of 300 and $375 \mathrm{~kg} \mathrm{ha}^{-1} \mathrm{Si}$. The sandy soil studied here is impoverished in micronutrients (Silva et al., 2019); therefore, such an effect likely occurred due to the input of micronutrients as impurities in the fertilizer.

Silicon fertilization has been shown to increase the $\mathrm{N}$ accumulation of cowpea (Mali \& Aery, 2008) and rice plants (Pati et al., 2016). Diatomite also improved the efficient use of $\mathrm{N}$ by rice through alterations in the metabolism of nitrogen compounds and their distribution in the plant (Detmann et al., 2012). 

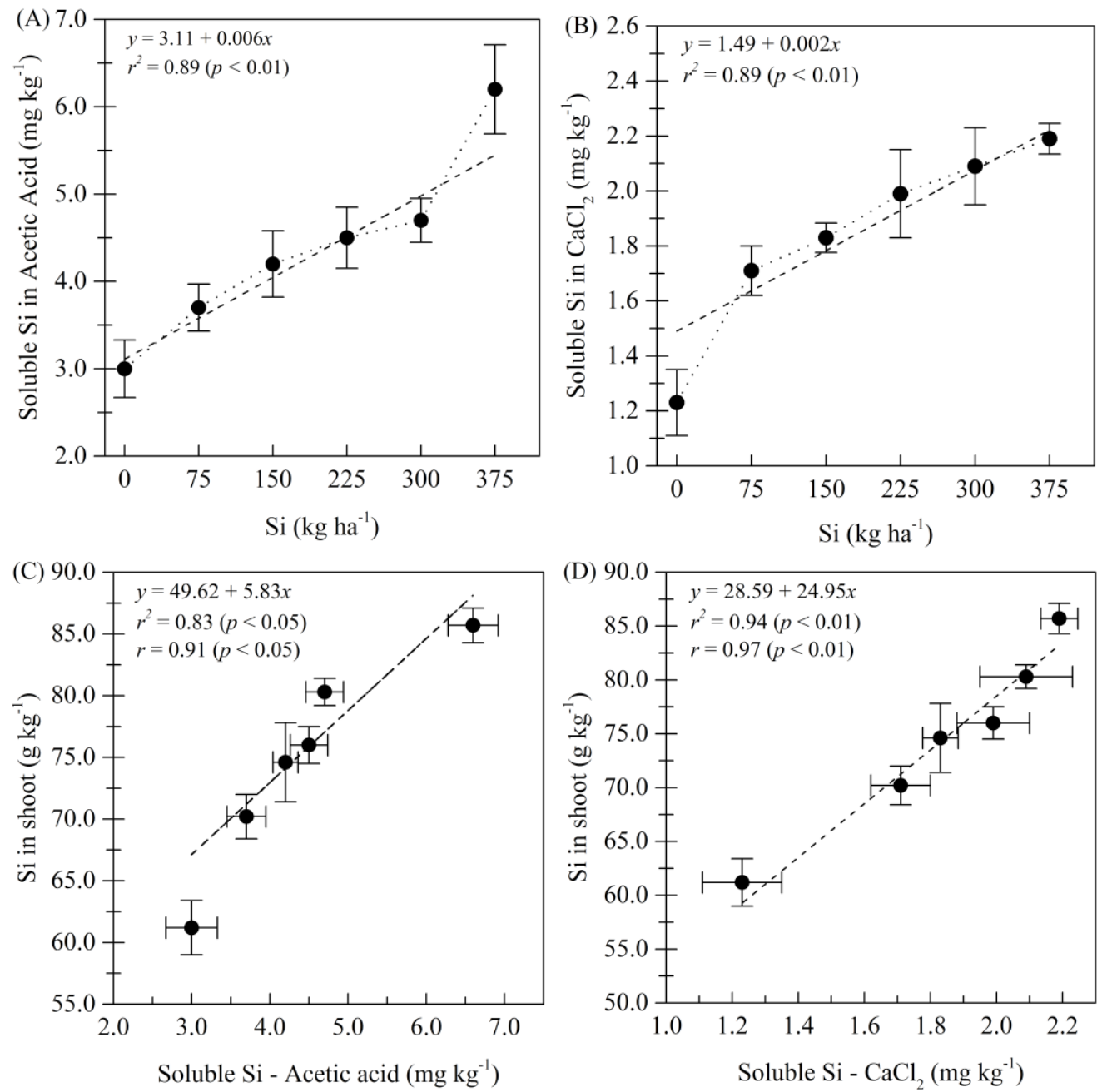

Figure 1. Mean contents ( \pm standard deviation) of soluble silicon extracted with acetic acid $\left(0.5 \mathrm{~mol} \mathrm{~L}^{-1}\right)$ and CaCl $\left(0.01 \mathrm{~mol} \mathrm{~L}^{-1}\right)$ in Arenosol fertilized with diatomite (A - B). Relationship between the Si contents in shoot of sugarcane and the soluble content in the soil (C - D). $p<0.01$ or 0.05 significant at 1 and $5 \%$ probability by ANOVA, respectively.
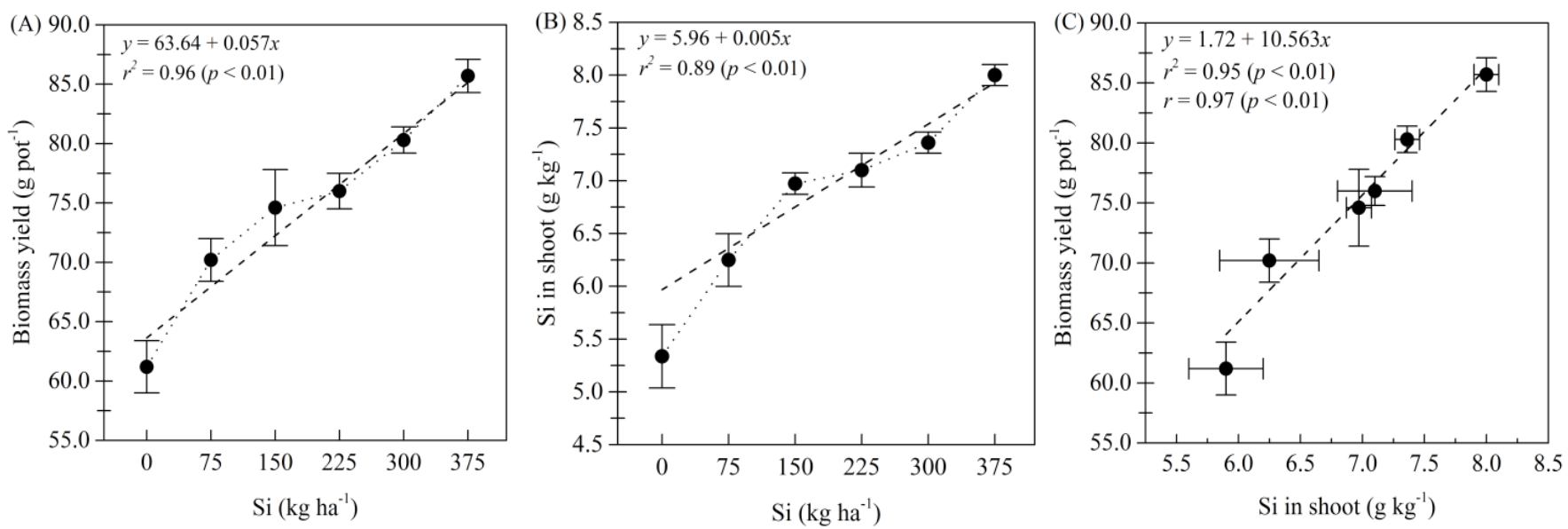

Figure 2. Mean values ( \pm standard deviation) of biomass $(A)$ and silicon concentration $(B)$ in shoot of sugarcane plants grown in Arenosol fertilized with diatomite. Relationship between biomass production and Si content in shoot (C). $p<0.01$ significant at $1 \%$ probability by ANOVA.

The increased $\mathrm{P}$ concentration in the shoots as a function of the fertilizer supply to soils are in agreement with the role of $\mathrm{Si}$ in the $P$ accumulation by Graminae species (Eneji et al., 2008). The main beneficial effect of Si on plant $P$ uptake is to increased soil
$P$ availability, especially in tropical regions with highly weathered soils and high $\mathrm{P}$ adsorption capacity (Eneji et al., 2008). Competition between soluble silicates $\left(\mathrm{H}_{3} \mathrm{O}_{4} \mathrm{Si}\right)$ and phosphates (as $\mathrm{H}_{2} \mathrm{PO}_{4}^{-}$) for binding sites on soil colloids can enhance the $\mathrm{P}$ 
Table 3. Mean concentrations ( \pm standard deviation) of nutrients in the shoots of sugarcane cultivated in an Arenosol amended with diatomite.

\begin{tabular}{|c|c|c|c|c|c|c|c|}
\hline \multirow{2}{*}{$\begin{array}{c}\text { Si } \\
\left(\mathrm{kg} \mathrm{ha}^{-1}\right)\end{array}$} & Nitrogen & Phosphorus & Potassium & Iron & Manganese & Copper & $\overline{\text { Zinc }}$ \\
\hline & \multicolumn{3}{|c|}{$\left(\mathrm{g} \mathrm{kg}^{-1}\right)$} & \multicolumn{4}{|c|}{$\left(\mathrm{mg} \mathrm{kg}^{-1}\right)$} \\
\hline 0.0 & $15.4 \pm 0.1 d$ & $4.4 \pm 0.0 b$ & $14.0 \pm 1.5 \mathrm{~ns}$ & $77.5 \pm 0.6 n s$ & $110.0 \pm 12.0 \mathrm{~b}$ & $15.3 \pm 1.2 \mathrm{a}$ & $48.8 \pm 8.1 \mathrm{~b}$ \\
\hline 75.0 & $18.6 \pm 0.3 b$ & $5.2 \pm 0.8 \mathrm{ab}$ & $15.2 \pm 0.0 \mathrm{~ns}$ & $81.4 \pm 5.1 \mathrm{~ns}$ & $135.0 \pm 15.0 \mathrm{ab}$ & $13.6 \pm 0.2 a b$ & $53.3 \pm 6.7 a b$ \\
\hline 225.0 & $20.6 \pm 2.1 a$ & $6.7 \pm 0.1 a$ & $16.3 \pm 5.0 \mathrm{~ns}$ & $88.1 \pm 0.1 \mathrm{~ns}$ & $168.0 \pm 31.0 \mathrm{ab}$ & $12.2 \pm 1.0 \mathrm{~b}$ & $61.7 \pm 9.8 a b$ \\
\hline 300.0 & $17.9 \pm 0.5 c$ & $6.2 \pm 0.1 \mathrm{a}$ & $16.8 \pm 0.0 \mathrm{~ns}$ & $85.5 \pm 3.5 \mathrm{~ns}$ & $175.0 \pm 9.0 \mathrm{a}$ & $11.7 \pm 0.9 b$ & $62.3 \pm 4.6 a b$ \\
\hline
\end{tabular}

Values followed by the same letter in the column do not differ statistically by the Tukey test $(p>0.05)$. CEC cation exchange capacity.

absorption by plants (Schaller et al., 2019). Additionally, studies have shown that $\mathrm{Si}$ can also improve the nutritional status of $\mathrm{P}$ in the plant by increasing photosynthetic phosphorylation; reducing the unnecessary absorption of Fe and $\mathrm{Mn}$ (Ma et al., 2004) and increasing P translocation in the plant (Greger et al., 2018). However, Si rates higher than $400 \mathrm{~kg} \mathrm{ha}^{-1}$ can diminished P uptake owing to antagonistic effects (Nascimento et al., 2020).

In general, the results showed that sugarcane cultivated in the sandy soils of NE Brazil could significantly benefit from the application of diatomite. The Si fertilizer increased plant biomass and improved the use of nutrient. These effects were directly related to the accumulation of $\mathrm{Si}$ by the crop, but effects on the soil, such as increased nutrient availability and water retention, probably played a role (Abdalla, 2010). Field experiments are warranted to confirm the diatomite potential to increase sugarcane yields and nutritional status.

\section{Conclusions}

Sugarcane responded positively to fertilization with diatomite in the soil studied here. The fertilizer was efficient in supplying available $\mathrm{Si}$ in the soil and increased $\mathrm{Si}$ concentration in the plant. Silicon accumulation was related to higher biomass and improved plant nutritional status.

The addition of diatomite altered the chemistry of the studied soil, significantly increasing $\mathrm{P}, \mathrm{K}, \mathrm{Mn}, \mathrm{Cu}$ available contents, and the cationic exchangeable capacity. The diatomite application increased the concentrations of $N, P$, $\mathrm{Mn}, \mathrm{Cu}$, and $\mathrm{Zn}$ in shoots, suggesting that the fertilizer can play a role in the efficient use of nutrients by sugarcane grown on Si-depleted soils.

The extractant $0.01 \mathrm{~mol} \mathrm{~L}^{-1} \mathrm{CaCl}_{2}$ was better correlated with $\mathrm{Si}$ concentration in plants than $0.5 \mathrm{~mol} \mathrm{~L}^{-1}$ acetic acid, although both extractants posed a good correlation with $\mathrm{Si}$ concentration in shoots. Therefore, $\mathrm{CaCl}_{2}$ is the recommended extractant to estimate $\mathrm{Si}$ availability in sandy soil because of its higher efficiency and lower cost.

\section{Literature Cited}

Abdalla, M. M. Sustainable effects of diatomite on the growth criteria and phytochemical contents of Vicia faba plants. Agriculture and Biology Journal of North America, v. 1, n. 5, p. 1076-1089, 2010. https://doi.org/10.5251/abjna.2010.1.5.1076.1089.
Akin, S. J. M.; Schembre, S.K.; Bhat S. K.; A.R. Kovscek. Spontaneous imbibition characteristics of diatomite. Journal of Petroleum Science and Engineering, v. 25, n. 3-4, p. 149-165, 2000. https:// doi.org/10.1016/S0920-4105(00)00010-3.

Alvarez, V. V. H. Equilíbrio de formas disponíveis de fósforo e enxofre em dois Latossolos de Minas Gerais. Viçosa: Universidade Federal de Viçosa, 1974. 125p. Masters Dissertation.

Amin, M.; Ahmad, R.; Ali, A.; Hussain, I.; Mahmood, R.; Aslam, M.; Lee, D.J. Influence of silicon fertilization on maize performance under limited water supply. Silicon, v.10, p.177-183, 2018. http:// doi.org/10.1007/s12633-015-9372-x.

Bakr, H. E. G. M. M. Diatomite: its characterization, modifications and applications. Asian Journal of Materials Science, v. 2, n. 3, p. 121 136, 2010. https://doi.org/10.3923/ajmskr.2010.121.136.

Camargo, M.S.; Bezerra, B.K.L.; Vitti, A.C.; Silva, M.A.; Oliveira, A.L. Silicon fertilization reduces the deleterious effects of water deficit in sugarcane. Journal of Soil Science and Plant Nutrition, v.14, n.1, p.99-111, 2017. https://doi.org/10.4067/S071895162017005000008.

Camargo, M.S.; Rocha, G.; Korndörfer, G.H. Silicate fertilization of tropical soils: silicon available and recovery index of sugarcane. Revista Brasileira de Ciência do Solo, v.37, n.5, p.1267-1275, 2013. https://doi.org/10.1590/S0100-06832013000500016.

Casaroli, D.; Jong van Lier, Q. de. Critérios para determinação da capacidade de vaso. Revista Brasileira de Ciência do Solo, v. 32 , n. 1 , p. 59-66, 2008. https://doi.org/10.1590/s010006832008000100007.

Companhia Nacional de Abastecimento - Conab. Acompanhamento da Safra Brasileira de Cana-de-açúcar. Brasília: Conab, 2020. 62p. (v. 7 - safra 2019/20, n. 1, primeiro levantamento). https://www. conab.gov.br/info-agro/safras/cana/boletim-da-safra-de-canade-acucar/item/download/31644_17890999b4a4d79a07b06a7 5babbb5e2. 13 May. 2020.

Crusciol, C.A.C.; Arruda, D.P.; Fernandes, A.M.; Antonangelo, J.A.; Alleoni, L.R.F.; Nascimento, C.A.C.; Rossato, O.B.; MacCray, J.M. Methods and extractants to evaluate silicon availability for sugarcane. Scientific Reports, v. 8, n. 1, p. 1-14, 2018. https://doi. org/10.1038/s41598-018-19240-1.

Detmann, K. C.; Araújo, W.; Martins, S. C.; Sanglard, L. M.; Reis, J. V.; Detmann. E.; Rodrigues, F. A.; Nunes-Nesi, A.; Fernie, A. R.; Damatta, F. M. Silicon nutrition increases grain yield, which, in turn, exerts a feed-forward stimulation of photosynthetic rates via enhanced mesophyll conductance and alters primary metabolism in rice. New Phytologist, v. 196, n. 3, p. 752-762, 2012. https://doi.org/10.1111/j.1469-8137.2012.04299.x. 
Elliot, C.L.; Snyder, G.H. Autoclave-induced digestion for the colorimetric determination of silicon in rice straw. Journal of Agricultural and Food Chemistry, v.39, n.6, p.1118-1119, 1991. https://doi.org/10.1021/jf00006a024.

Empresa Brasileira de pesquisa Agropecuária - Embrapa. Manual de análises químicas de solos, plantas e fertilizantes. Brasília: Embrapa Informação Tecnológica, 2011. 627p.

Eneji, A. E.; Inanaga, S.; Muranaka, S.; Li, J.; Hattori, T.; An, P.; Tsuji, W. Growth and nutrient use in four grasses under drought stress as mediated by silicon fertilizers. Journal of Plant Nutrition, v. 31, n. 2, p. 355-365, 2008. https://doi.org/10.1080/01904160801894913.

Garbanzo, G.; Molina, E.; Cabalceta-Aguillar, G. Evaluación de Si aplicado al suelo en el crecimiento, absorción y severidad de enfermedades en vivero de palma aceitera. Agronomía Costarricense, v. 42, n. 1, p. 91-114, 2018. https://doi. org/10.15517/rac.v42i1.32198.

Greger, M.; Landberg, T.; Vaculík, M. Silicon influences soil availability and accumulation of mineral nutrients in various plant species. Plants, $v$. 7, n. 2, e41, 2018. https://doi.org/10.3390/plants7020041.

Haynes, R. J. A contemporary overview of silicon availability in agricultural soils. Journal of Plant Nutrition and Soil Science, v. 177, n. 6, p. 831-844, 2014. https://doi.org/10.1002/jpln.201400202.

IUSS Working Group WRB. World Reference Base for Soil Resources 2014, update 2015. International soil classification systems for naming soils and creating legends for soil maps (Update 2015). Rome: FAO, 2015. 192p. (FAO. World Soil Resources Reports, 106). http://www.fao.org/3/a-i3794en.pdf. 29 May. 2020.

Keeping, M.G. Uptake of silicon by sugarcane from applied sources may not reflect plant-available soil silicon and total silicon content of sources. Frontiers in Plant Science, v.8, e760, 2017. https://doi.org/10.3389/fpls.2017.00760.

Korndörfer, G.H.; Coelho, N.M.; Snyder, G.H.; Mizutani, C.T. Evaluation of soil extractants for silicon availability in upland rice. Revista Brasileira de Ciência do Solo, v.23, n.1, p.101-106, 1999. https:// doi.org/10.1590/S0100-06831999000100013.

Liang, Y.; Nikolic, M.; Bélanger, R.; Gong, H.; Song, A. Silicon in agriculture: from theory to practice. New York: Springer, 2015. $235 p$.

Ma, J. F.; Mitani, N.; Nagao, S.; Konishi, S.; Tamai, K.; Iwashita, T.; Yano, $M$. Characterization of the silicon uptake system and molecular mapping of the silicon transporter gene in rice. Plant Physiology, v. 136, n. 2, p. 3284-3289, 2004. https://doi.org/10.1104/ pp.104.047365.

Mali, M.; Aery, N.C. Silicon effects on nodule growth, dry-matter production, and mineral nutrition of cowpea (Vigna unguiculata). Journal of Plant Nutrition and Soil Science, v. 171, n. 6, p. 835840, 2008. https://doi.org/10.1002/jpln.200700362.

Matichenkov, V.V.; Bocharnikova, E.A. The relationship between silicon and soil physical and chemical properties. In: Datnoff, L.E.; Snyder, G.H.; Korndörfer, G.H. (Eds.). Silicon in agriculture. Amsterdam: Elsevier, 2001. p.209-219.
Miles, N.; Manson, A.; Rhodes, R.; van Antwerpen. R.; Weigel, A. Extractable silicon in soils of the South African sugar industry and relationships with crop uptake. Communications in Soil Science and Plant Analysis, v. 45, n. 22, p. 2949-2958, 2014. https://doi. org/10.1080/00103624.2014.956881.

Nascimento, C. W. A.; Amarasiriwardena, D.; Xing, B. Comparison of natural organic acids and synthetic chelates at enhancing phytoextraction of metals from a multi-metal contaminated soil. Environmental Pollution, v. 140, n.1, p. 114-123, 2006. https:// doi.org/10.1016/j.envpol.2005.06.017.

Nascimento, C. W. A.; de Souza Nunes, G. H.; Preston, H. A. F.; da Silva, F. B. V.; Preston, W.; Loureiro, F. L. C. Influence of silicon fertilization on nutrient accumulation, yield and fruit quality of melon grown in Northeastern Brazil. Silicon, v. 12, n. 4, p. $937-$ 943, 2020. https://doi.org/10.1007/s12633-019-00187-5.

Nascimento, C.W.A.; Cunha, K.P.V. Silicon and heavy metal: tolerance of plants. In: Tripathi, D.K.; Singh, V.P.; Ahmad, P.; Chauhan, D.K.; Prasad, S.M. (Eds.). Silicon in agriculture: advances and future prospects. London: CRC Press, 2015. p.83-100.

Pati, S.; Pal, B.; Badole, S.; Hazra, G.C.; Mandal, B. Effect of silicone fertilization on growth, yield, and nutrient uptake of rice. Communications in Soil Science and Plant Analysis, v.47, n.3, p.284-290, 2016. http://doi.org/10.1080/00103624.2015.11227 97.

Sandhya, K.; Prakash, N.B. Bioavailability of silicon from different sources and its effect on the yield of rice in acidic, neutral, and alkaline soils of Karnataka, South India. Communications in Soil Science and Plant Analysis, v.50, n.3, p.295-306, 2019. http://doi. org/10.1080/00103624.2018.1563096.

Schaller, J.; Faucherre, S.; Joss, H.; Obst, M.; Goeckede, M.; PlanerFriedrich, B.; Peiffer, S.; Gilfedder, B.; Elberling, B. Silicon increases the phosphorus availability of Arctic soils. Scientific Reports, v. 9, n. 1, p. 1-11, 2019. https://doi.org/10.1038/s41598-018-37104-6.

Silva, R. D. C. F. da.; Silva, F. B. V. da.; Biondi, C. M.; Nascimento, C. W. A. D.; Oliveira, E. C. A. D. Assessing the content of micronutrients in soils and sugarcane in different pedogeological contexts of Northeastern Brazil. Revista Brasileira de Ciência do Solo, v. 43, e0180228, 2019. https://doi.org/10.1590/18069657rb cs20180228.

Tubana, B. S.; Babu, T.; Datnoff, L. A review of silicon in soils and plants and its role in US agriculture: history and future perspectives. Soil Science, v. 181, n. 9/10, p. 393-411, 2016. https://doi.org/10.1097/SS.0000000000000179.

Wang, S.; Liu, P.; Chen, D.; Yin, L.; Li, H.; Deng, X. Silicon enhanced salt tolerance by improving the root water uptake and decreasing the ion toxicity in cucumber. Frontiers in Plant Science, v.6, e759, 2015. http://doi.org/10.3389/fpls.2015.00759.

White, B.; Tubana, B. S.; Babu, T.; Mascagni, H.; Agostinho, F.; Datnoff, L. E.; Harrison, S. Effect of silicate slag application on wheat grown under two nitrogen rates. Plants, v. 6, n.4, e47, 2017. https://doi. org/10.3390/plants6040047. 